\title{
Ready to Change the World? Start Here!: What Are Jesuits Doing in East Africa?
}

\author{
James Strzok, S.J. \\ St Peter Claver High School, Dodoma, Tanzania \\ strzokj@gmail.com
}

\begin{abstract}
This article represents a case study of Jesuit activities in Kenya, Tanzania and Uganda, specifically regarding sustainable practices, through a reflection of the author's own itinerary. It highlights some of the opportunities that construction and infrastructure development offers for harnessing solar energy and utilizing eco-friendly methods, such as hydraform technology, bio-latrines as a means of methane gas production, solar energy, and especially geothermal energy as an abundant resource in Kenya's Great Rift Valley. Additionally, the article outlines the crucial role of trees in ecosystems as a constructive means of responding to climate change based on the process of carbon capture, while illustrating tree planting as a service in an educational context. Particular focus is given to the sibling schools of St Peter Claver High School and Ocer Campion Jesuit College in Dodoma, the capital of Tanzania, which constitute a model of sorts exhibiting these best practices for the community.
\end{abstract}

\section{Keywords}

East Africa - climate change - Great Rift Valley - solar energy - geothermal energy bio-latrines - planting trees 
Praise to you Lord, through our sister, mother earth, who, sustains us and governs us, and, who produces various fruits with colored flowers and herbs-Saint Francis of Assisi

\section{Introduction}

East Africa's complex geophysical features, its highlands, volcanoes, vast plains, rainforests, deserts, lakes, and rivers are in large part interrelated with the Great Rift Valley. Under the African Plate, the tectonic plate on which the continent rests, huge convection currents of molten magma arise from the depths of the earth's interior, relentlessly expanding the continent's crust, and thereby opening the Great Rift Valley further. This geothermal activity, as a result, creates frequent, but relatively mild earthquakes, and it has also made possible the volcanoes and great lakes that make East Africa's varied topography distinctive. The heat contained in the deep molten magma beneath the rift valley and that is stored in the lava of active or dormant volcanoes, however, is only just beginning to be tapped as a source of green geothermal energy by companies in the region, such as Kenya Electricity Generating Company (KenGen). This energy source, almost unlimited in supply, holds immense promise for greater possibilities as a kind of green energy that can address Africa's growing needs.

This slow, relentless process coupled with Africa's position along the equator, gave rise to the human race about 1,000,00o years ago. Now the same human species, with its global population of over seven billion, is the prime player as the major cause in changing the climate of its home, planet Earth. Except for an occasional earthquake or volcano, most people are unaware of the underground changes that fundamentally govern our lives. In the same way, still few people are aware of the natural and anthropogenic processes that affect climate change, which is already profoundly changing — and will continue to do so-our lives on Earth.

For instance, on October 24, 2015, Hurricane Patricia, the strongest recorded hurricane in the Western Hemisphere, slammed into land near Puerto Vallarta, Mexico. This category 5 hurricane packed up to $200 \mathrm{mph}$ winds, which 
subsequently created an eighteen-foot surge. The eye of the hurricane missed Puerto Vallarta and eventually exhausted itself against a few coastal villages and the surrounding high mountains, thereby causing relatively minor damage. Both the 2015 Memorial Day storm that caused record floods in Houston, Texas, and Hurricane Patricia were two of several category 4 and 5 storms, respectively, and both were accredited in 2015 to anthropogenic climate change.

While continental drift is naturally outside human control, the causes of such storms that are cited above are not, and certainly more storms and other extraordinary climatic events will come that can be correlated to anthropogenic causes, as the International Panel on Climate Change (IPCC) states. In the most recent 2015 publication Climate Change 2014 Synthesis Report (SYR), which distills and integrates its previous reports in 2011 to 2014, IPCC asserts that its findings are unequivocal:

The SYR confirms that human influence on the climate system is clear and is growing, with impacts observed across all continents and oceans. Many of the observed changes since the 1950s are unprecedented over decades to millennia. The IPPC is now ninety-five percent certain that humans are the main cause of global warming. In addition, SYR finds that the more human activities disrupt the climate, the greater the risks of severe, pervasive, and irreversible impacts for people and ecosystems, and long-lasting changes in all components of the climate system. ${ }^{1}$

While there are ecological ramifications from the impact of climate change, as we will see through a personal account in the following section, these circumstances are especially having adverse effects on Tanzania and many other equatorial countries in Africa. While similar scenarios may be evident elsewhere, a specific case can be found in the 2015 drought that the entire Dodoma Region suffered when the seasonal rains began and then ended after only three weeks, resulting in a failed harvest of sunflowers, ground nuts, and maize, all of which are essential to the livelihood and the economy of this huge region that comprises much of the central interior of Tanzania.

1 Intergovernmental Panel on Climate Change, Climate Change 2014: Synthesis Report; Contribution of Working Groups I, II and III to the Fifth Assessment Report of the Intergovernmental Panel on Climate Change, ed. Core Writing Team, Rajendra K. Pachauri, and Leo Meyer (Geneva: IPCC, 2015), available online at: http://www.ipcc.ch/pdf/assessment-report/ar5/ syr/SYR_AR5_FINAL_full_wcover.pdf (accessed May 27, 2016). For this excerpt, see Michel Jarraud and Achim Steiner, "Foreword," v. 


\section{Summer Solstice, 2015}

It is late September here in central Tanzania, in what has been an unusually dry year. In the midst of a drought, there are already pockets of famine developing due to regional crop failure. These conditions will continue for the next several months, until the anticipated November rains begin and only then vegetables, beans, sunflowers, millet, grapes, and maize can begin to grow and mature. Last year's seasonal November-to-February rains, however, were scant and sporadic, leading some local people to blame it on the eleven-year drought cycle. Having served as the supervisor of famine relief in Turkana, Kenya, and in central Tanzania from the Jesuit provincial offices in Nairobi in 2004, I can attest to the severe drought and famine that had struck East Africa eleven years ago.

While typically this eleven-year drought cycle may suffice to explain this natural occurrence, other authorities, especially earth scientists who study various stressors to the earth's climate system, are blaming increasing temperatures upon climate change that is at its basis a result of human-made activity. The SYR, cited above, can now confirm this. In light of these scientific findings, the repercussions and responsibilities with regards to these droughts take a different significance and relevance. As a regional report of a similar type to the SYR, this one from the African Center for Strategic Studies, on October 19, 2015, states the following:

Government officials say this year the drought is just as bad as those infamous events that sparked famines in $1965 / 66,1972 / 73$ and $1984 / 85$. It is harvesting time in North Wollo, the most drought-sensitive area of the country, and farmers here say their crops have failed. The annual meher [seasonal] rains fell only for three days. Hunger and malnutrition has risen sharply, affecting millions. ${ }^{2}$

Such events, like superstorms and local changes in the rain cycle, indicate the basic impact of climate change. Indeed, as I mentioned humans cannot stake a claim to the movement of tectonic plates in East Africa, yet climate change

2 Arron Reza Merat, "Ethiopia Is Facing Its Most Severe Drought in 30 Years: Can the Government Stop Famine This Time?," Global Post, 16 October 2015, http://www.globalpost .com/article/6670119/2015/10/16/ethiopia-facing-its-worst-drought-30-years-can-govern ment-stop-famine (accessed June 10, 2016). In East Africa, including countries such as Ethiopia as well as Kenya and Tanzania, meher is a main crop season in the summer months and farmers rely upon it as one of the two rainy seasons. 
is another matter. Myself as an earth scientist and an educationalist, I credit both natural cyclical causes and - upon the evidence of professional earth scientists working for the UN's IPCC - blame increasing negative human activity for such climatic manifestations.

Let me diverge slightly from the topic of climate change though in order to share my background. My parents, neither one of them highly educated, wished the best Catholic education for their children. We five boys were sent to Campion Jesuit High School (CJHS), in Prairie du Chien, Wisconsin, where, our lives and minds were opened beyond our village. At CJHS, we lived alongside and befriended fellow students from all over the USA. We encountered a personal, immanent, loving God as Creator and the sustaining presence of creation; and we learned that we had a part in creation's unfolding. It was during my senior retreat in 1957 that I heard and responded to an inner call to become a Jesuit priest. Shortly thereafter, I entered the Jesuit novitiate, and experienced another significant event that would change my life forever.

On October 4, 1957, Russia launched Sputnik 2 that carried Kairi, a monkey, into Earth's orbit. Our novice master, Joe Sheehan, S.J., permitted us listen that evening to the news announcement and the transmitted "beep, beep" of its radio to the earth stations that relayed the signals. It did not take a rocket scientist to understand that if Russians could launch Sputnik, they might also send bombs into orbit. For us as Americans, living at the height of the Cold War with the Communist regime, we were terrified. On July 28, 1958, the National Atmospheric and Space Administration (NASA) was formed. In 1961, as John F. Kennedy became the thirty-fifth us president, with the promise to send an American to the moon by the end of the 1960 , the "space race" remained not far from my own consciousness, and so my formation as a Jesuit while studying whether it be philosophy, the arts, or the sciences.

Like most of my classmates who were training to become Jesuit priests, I majored in a field other than philosophy and theology. In 1964, I received my undergraduate degree in chemistry and physics from Spring Hill College, in Mobile, Alabama. After two years of teaching, I did graduate work in earth sciences at St. Louis University's geophysics department, during the years of the Mercury, Gemini, and Apollo programs and when an American astronaut, Neil Armstrong — as Kennedy promised—walked on the moon in July 1969. I was ordained as a priest in 1970. During those years with the space missions, I taught earth sciences at my alma mater, cJHs, in Prairie du Chien, Wisconsin and a few years later, at Holy Rosary Mission in South Dakota. And so my graduate studies in both earth sciences and theology was infused by the current events particularly as they were occurring in space science-in more ways than one, since NASA even funded part of my studies. 
Indeed, concurrently, we heard another voice in those years of formation while studying chemistry that spoke of a responsibility to Earth. Rachel Carson, whose groundbreaking book Silent Spring opened our consciousness in order to recognize the urgent need to protect our environment from dangerous chemicals, represented a vital reminder of our participation and responsibility in creation's unfolding. ${ }^{3}$ Although, at that time, we could not yet realize how human activity is changing the entire planet's climate, this perspective helped underline the importance of the environmental as a part of our Jesuit missions. For me, in particular, it influenced the way I taught earth sciences at CJHS and at the Holy Rosary Mission.

After sixteen years of teaching in the United States, I was missioned to Uganda and then to Kenya in order to teach and especially also to apply my scientific background to building structures for the East African province, which was still growing. Meanwhile, I was never far removed from learning further about developments in environmental studies. Working for thirteen years in Nairobi, Kenya, the home of the United Nations' Environmental Program (UNEP), I avidly read and studied the written reports of IPCC that were offered to me by Etienne Triaille, S.J. (b.1934), advisor to the Holy See Mission to UNEP and UN-Habitat. Those reports became a critical resource for my own apostolic mission, and how I applied, with the help and collaboration of many other Jesuits and non-Jesuits, the training and formation I received that I could share in various environments and through various projects. In all of these works, which I outline below, I am convinced that I was using my secular education and Jesuit charism to pass on to others what we know and what we value.

Having provided a personal itinerary, the subsequent sections provide focus around a specific issue or an environmental best practice and begin to illustrate the environmental context for these projects. As a missionary in East Africa, my labors were first dedicated to the construction of buildings through sound environmental methods but that work now takes greater variety around different ecological issues and concerns that are still related to the built environment Jesuits inhabit in East Africa.

\section{Geothermal Energy}

Nairobi, located on the edge of the Great Rift Valley, is situated in a region where one million years ago volcanoes erupted along the rift, spewing hundreds of

3 Rachel Carson, Silent Spring (Boston: Houghton Mifflin Harcourt, 1961). 
feet of hot ash over the environs. As the hot ash fell in thick hot layers, it was subsequently compressed by gravity to form the tuff rocks that today are commonly called "Nairobi stone," a soft, grey-to-buff-colored stone, that can be easily quarried and worked by hand and so is commonly used for construction throughout Nairobi.

In 2001, as we made the necessary site-preparations for the healthcare facility at the Pedro Arrupe Jesuit Community, I took measurements of soil composition and specifically its temperature, while also measuring the temperature of our well water. ${ }^{4}$ As a result, I discovered that the heat from extinct volcanoes was still locked into the surrounding tuff. The temperature of the water in our 157-meter-deep well, for example, was thirty degrees centigrade-the temperature of a warm summer day. This fact immediately led to the realization that we could use the heat in our borehole water as a source for heating our buildings during the cold season (June to August), when outside temperatures can reach as low as ten degrees centigrade at night. With the mathematical calculations of the heat content in our borehole water suggesting that it was sufficient, the engineers were convinced to design geothermal heating system for our chapel. Insulating our high-level water tank above the borehole and the two-inch water supply pipes supplying water to our chapel, the chapel today is capably heated in winter by geothermal water-while solar panels heat the other five buildings on site.

Six years later, as our first well began failing, we needed to drill a second bore hole to a depth of 300 meters. The temperature in this new well, thirtythree degrees centigrade, we learned is warm enough to heat all of the other buildings. At that point in time, it was too late to retrofit the original buildings, because the requisite underfloor piping installation and insulation would need to be in place as the buildings were being built, in order to utilize this new source that could provide higher heat energy for the cold seasons. Nevertheless, with this realization and opportunity, the plan to utilize geothermal energy for heating the residences and other buildings now could be implemented in Nairobi.

Geothermal heat, however, is not a novel development in East Africa. For instance, Kenya's flagship utility company that specializes in green, hydroelectric, geothermal, and wind power is KenGen, a leader in East Africa for alternative and green energy. ${ }^{5}$ While hydroelectricity is its leading source of

4 The construction of Pedro Arrupe Jesuit Community, a healthcare facility for aging and ailing Jesuits in Nairobi, commenced in 2001 under the author's supervision.

5 For its various geothermal projects, including the construction of the world's largest geothermal plant, see KenGen, "Integrated Annual Report and Financial Statements: For the Year 
power, the company has five geothermal power plants of 493 megawatts, with four geothermal power stations that are situated in the Great Rift Valley. Our modest efforts to utilize alternative and sustainable energy pales in comparison to national utility companies, such as KenGen, yet such small actions that communities collectively undertake can have a more significant impact. Recently this conviction Pope Francis affirmed in his encyclical Laudato si', advocating for simple and yet profound ways to address the growing environmental crisis. ${ }^{6}$

While strictly speaking not a form of geothermal energy, the manufacturing and use of hydraform blocks also illustrates another simple example of eco-friendly practice. Back in 2007, our young Eastern Africa province set goals to build at least one school in each of the five nations of our province. ${ }^{7}$ The superior of the Ugandan mission, Tony Wach, S.J. (b.1943), invited me to collaborate with him in building a secondary school in the war-torn Acholi land of northern Uganda, a region devastated by approximately twenty years of civil war between the Lord's Resistance Army - the infamous Kony Rebel group led by Joseph Kony (b.1961) — and Uganda's national army (NRM), and where most rural people were living in internally displaced (IDP) camps during those years. According to Wach's vision, a Jesuit school was proposed in the vicinity of the town of Gulu. After several years of scouting specific sites and numerous contacts, with the aid of local clergy and Reagan Okumu, a parliament representative, the Episcopalian Abinonie Okumu clan donated ninetyeight acres of communal land on which the province could build a school. This

Ended 30 June 2015," http://www.kengen.co.ke/sites/default/files/financial-reports/2015\%20 KenGen\%20Annual\%2oReport.pdf (accessed June 10, 2016).

6 Ed. note: See esp. Francis, Laudato si', May 24, 2015, para. 179, and available online at: http:// w2.vatican.va/content/francesco/en/encyclicals/documents/papa-francesco_20150524_ enciclica-laudato-si.html (accessed June 10, 2016). Herein Pope Francis vociferously advocates for these kinds of projects: "In some places, cooperatives are being developed to exploit renewable sources of energy which ensure local self-sufficiency and even the sale of surplus energy." See para. 213-14, wherein Pope Francis states that "ecological education" may take place in a multitude of settings and that an "integral education," like that which might take place in a household, occurs through "simple gestures." He continues to express that seminaries and houses of formations can be such a setting to "provide an education in responsible simplicity of life, in grateful contemplation of God's world, and in concern for the needs of the poor and the protection of the environment." See also para. 219.

7 Established in 1986 by Peter-Hans Kolvenbach, after it was declared an independent region by Pedro Arrupe in 1976, the province includes Jesuit communities in Ethiopia, Kenya, Sudan, Tanzania, and Uganda. See Jesuits of Eastern Africa, http://www.jesuits-aor.net/about-us/ history/eastern-africa-province/ (accessed June 10, 2016). 
led to planning and building a mixed boarding school for about 1,00o students called Ocer Campion Jesuit College (OCJC), with its buildings designed according to the aim to respect and to even enhance the existing environment, while expressing Acholi culture.

Hydraform building blocks, accordingly, became the ideal solution for the basic construction materials at ocjc. This cost-effective method manufactures interlocking blocks, which are comprised of about seventy-eight percent local subsurface soil, ${ }^{8}$ that are pressed hydraulically into formed blocks that resemble massive Lego blocks, and similarly interlock on all sides. Under ordinary circumstances, the blocks are solid enough to construct buildings that are three floors high. In the ocJC buildings, the walls of these structures were secured and strengthened with ring beams as a protective measure against earthquakes. In the past, throughout the Acholi territory constructive materials typically—-for a building like those projected at ocJC—-consisted of mud and wattle, or burnt bricks, or concrete. In contrast, hydraform blocks are ecofriendly. Whereas the ordinary local burnt brick requires an enormous amount of energy to fire, and then to construct a wall itself demands for the mortar more cement, which is energy-intensive with respect to production and transport, hydraform blocks are a local solution that entails only a fraction of the energy for production, and yet it can be done in a sustainable manner. Moreover, its texture reflects the local rock and climate of the Acholi land that surrounds the site. This has become a standard practice, and is promising option for other Jesuit missions.

\section{Solar Energy}

An additional means of sustainable energy in East Africa is available through solar power. This became an aspect of my mission in this province as soon as I arrived. In 1987, for instance, I built Xavier House in Kampala, Uganda, designing and building our own solar water heaters at a time when such systems were not yet available on the local market. Among the first in Kampala and more broadly throughout the whole country to install solar-voltaic panels, this system was key for the community to maintain its ministries while the local Ugandan electrical grid habitually failed to provide electricity.

8 In sum, a hydraform block is a mixture of this subsurface soil, which consists of weathered granite composed mostly of aluminum silicate, iron oxides and silicates, called murram in the local language, in addition to twelve percent sand and silt and ten percent cement. 
More recently, during the construction of OCJC, a similar dilemma emerged on account of Umeme, Uganda's electric grid, not being accessible in Gulu. Consequently, we made a major investment in solar power. The original investment into solar energy is considerable, due to the panels, batteries, wiring, and inverters that need to be purchased. Huge crystalline 300-watt solar panels, regulators, large battery arrays, and inverters currently supply electricity to run our water pump, to light classrooms, to run a lab of sixty computers and other small appliances. The campus almost exclusively relies upon solar power. Nonetheless, the investment is repaid in savings that accrues due to the sustainable source and in the convenience of having electricity at all times, and circumventing the risk of load-sharing that afflicts the local electric grid.

\section{Bio-Latrines and Recycling}

Biogas that is generated from human waste and using wastewater as a means for growing crops is rarely seen in East Africa. Generally speaking, the notion of using human waste as cooking fuel is repugnant to many local people who are careful not to mix human waste with food. Animal manure, however, is more commonly accepted for agriculture. Yet human waste can be a useful source of methane gas, which does not contain any pathogens.

Presently, the technology to utilize biogas in this manner-particularly biolatrines, which produce methane gas - is being developed at some sites that belong to the province and is currently being applied in others. St Peter Claver High School is one such example, and its best practices are being replicated and implemented at nearby University of Dodoma, from which seven environmental engineers of the earth sciences department visited our campus in September 2015 in order to study the bio-latrines and sewer treatment system. The school, as a result, became a site as part of their environmental studies curriculum because it demonstrates methane as an alternate energy source and displays how to utilize the fertile, digested sewer effluent for watering trees and some plants.

Additionally, there are detailed plans at ocJC-St Peter Claver's sister school-for building bio-latrine toilets for the purposes of cooking food, which would replace wood as a cooking resource with methane gas. ${ }^{9} 1,000$ ocJC students and additional staff could easily supply enough fecal material to

9 For further information, contact Festo Ndonde of Ecological Sanitation Anaerobic Waste Conversion, Tabora, Tanzania, e-mail: fendonde@gmail.com. 
generate sufficient methane gas for cooking meals, which would reciprocally save a huge amount of trees that would have been otherwise cleared for fuel. Noting the cultural disdain for this notion, this operation becomes a useful educational resource that can draw upon both biology and chemistry to explain the bio-digesters.

As one walks along the sidewalk near the administration block of St Peter Claver High School, in Dodoma, there is a tall, green sign proclaiming: "St Peter Claver is a green campus-We dispose of waste, we recycle when we can, we plant trees." The campus is a showpiece for what can be done especially to utilize waste or sewer water, as the visit by experts from the local university might demonstrate. However, there is an added significance in this particular context. The campus becomes a sort of symbol for a community that recycles and intertwines that with the beauty of the campus. Elsewhere in Tanzania, plastic bags are ubiquitous. While fortunately there is a growing market for plastic bottles around East Africa and people can earn some extra money by gathering and selling plastic bottles, plastic bags typically are strewn across trees and fences. The sight of such trash is multiplied in many urban settings, dulling our sense of natural beauty, and creating a sort of visual wasteland. Customarily, in this region, most of the plastic waste is burnt despite widespread knowledge such fires release toxic, carcinogenic gases. Still, the level of plastic pollution is extreme. In contrast, those visitors to Rwanda admire its beauty and it represents a kind of showpiece as a country, and the visitors make such an observation due to its lack of plastic bags blowing around its streets. Rwanda prohibits the circulation of plastic bags - a gesture replicated in Kampala, but either ignored or unenforced. As of 2016, all of Tanzania is outlawing plastic bags. Amidst all of this, St Peter Claver High School might represent a showpiece as a school for its community.

\section{Tree Planting and Carbon Dioxide Capture}

The 2004 Nobel Peace Prize laureate and Kenya's own Wangari Maathai (1940-2011) had a simple solution to climate change and environmental degradation: plant trees. As an activist, Maathai used this dictum not only for political reasons but also environmental ones. ${ }^{10}$ As an ecological act, tree planting can play a crucial role in mitigating climate change. For one, trees effectively consume carbon dioxide, which is attributed as a major climate-changing gas, and are also valuable stores of carbon. This is known as carbon dioxide

\footnotetext{
10 See Wangari Maathai, Unbowed: A Memoir (New York: Alfred A. Knopf, 2006).
} 
capture. ${ }^{11}$ In terms of the ecosystem, a tree's canopy significantly softens the impact of raindrops on topsoil, lessening soil erosion, and furthermore tree roots open small channels into the soil and subsoil, allowing the slow drip of rain water from a trees' umbrella to percolate into the aquifers below the ground surface, restoring subsurface water. Conversely, when trees are cut along with their canopy and roots decay or are removed, the ground becomes distinctly hardened as a result. Wind typically erodes the unprotected soil further, and the long-term effect is desertification.

Integral to the significant achievement and ethical agenda of Wangari Maathai is her subsequent role as a model for students. In this regard, Maathai's dictum also has a long-lasting impact. After her reception of the Nobel Peace Prize, students from Nkaimurunya Primary (Government) School joined her Green Belt Movement, thanks to the efforts of their teachers who brought the lessons from this campaign's workshops back to the school. At Nkaimurunya, each child was assigned a single tree and instructed to care for that tree each morning, with water from a nearby Mbagathi River. At first, some parents complained about this new practice of fetching water for trees until the school earned its first environmental conservation award in 2007, which subsequently brought the school enough money to construct a new 30,000-liter rainwater tank and the connecting rainwater troughs that could fill it. In turn, Rotary International-an organization to which I belong as a member-assisted the school further with a borehole that enhanced the campus further allowing more trees to be planted and watered, besides giving it potable water. In partnership with the local Jesuit community, especially Vincent Soreng, S.J. (b.1936), Jim Strzok, S.J. (b.1939) - the author of this article himself-and Nkaimurunya's headmistress Terry MacOdemba, more than 15,000 trees and bushes were collectively planted with the assistance of students and workers. The Jesuit province's Mwangaza Retreat Centre, the Pedro Arrupe Jesuit Community, and the nearby Nkaimurunya Primary (Government) School are now renowned throughout Nairobi for their numerous trees and their verdant campuses.

At St Peter Claver High School alone, located in the semi-arid central plains of Tanzania, its groundskeeper, Soreng, and his assistants, planted over six thousand trees and even more bushes in order to stem the effect of deforestation, which is caused overwhelmingly so that local people can get

11 For further information, see IPCC, Carbon Dioxide Capture and Storage: Special Report, ed. Bert Metz, Ogunlade Davidson, Heleen de Coninck, Manuela Loos, and Leo Meyer (Cambridge:Cambridge University Press, 2005), https://www.ipcc.ch/pdf/special-reports/srccs/ srccs_wholereport.pdf (accessed June 10, 2016). 
access to charcoal that typically serves as the primary source of fuel and light, where neither propane gas nor electricity can be found. In areas like this, as is the case throughout Africa, trees are being cut down faster than they are being replanted and replaced, and this process simultaneously causes carbon dioxide to be released into the atmosphere as the wood or charcoal burns. Nevertheless, during the morning commute on the St Peter Claver High School bus, one might find every bicycle carrying a bag of charcoal from the surrounding highlands to the city center for sale in local markets. On a typical morning, that commute-only a twenty-minute trip-passes thirteen such bicycles, and this scenario is the same on three of the other roads that lead into Dodoma. Consequently, one can deduce that each morning there are one hundred bags of charcoal per hour being burnt in the surrounding forests, and then transported to Dodoma in order to provide charcoal for fuel and light for this capital city of approximately 300,000 . This might signal a dimension of the Jesuit school's role in the region as an educator. Yet it also underscores tree planting as a key part of the social apostolate in this region.

At OCJC, where bio-latrines are still in development, wood is still being used to cook foods for the school community. Tree planting in this case becomes a means of amending this deficit that the school is accruing. Defining the school's property boundary and also an effort to fully replace those trees that were previously cut for firewood, a nursery was created that eventually consisted of roughly 60,000 trees and plants. As previously mentioned, there are critical ways that trees can mitigate climate change, particularly for carbon dioxide capture. At the school's nursery, the fruit trees of course have added benefits.

During the 2004 drought in East Africa, the Eastern Africa province, assisted by a special fund from the Wisconsin province of the Society of Jesus, brought direct water- and food-relief to the central region of Tanzania and to Turkana, in northern Kenya. Ten percent of that grant was dedicated to rehabilitating wells, which are a crucial source of water in the region, especially during drought. ${ }^{12}$ Another five percent of the grant was used for planting neem trees, a kind of resistant, medicinal hardwood tree. ${ }^{13}$ Coincidentally, the easiest way

12 The northern Kenyan diocese of Lodwar that serves most of Turkana alone outfit two crews of men to keep the 120 wells in Turkana operating and the pumps in good repair during the drought. When a well fails, two days without water can cause death to livestock and people.

13 Neem translated into the local language, Kiswahili, is maroibaini. Arobaini meaning forty — or "the tree of forty uses" — is critical locally for its use in the treatment of malaria, high blood pressure, a host of other (forty) diseases, and also as an insecticide. 
to insure that these trees were planted and cared for until they were about two meters high was to enlist the local Catholic women groups. Women and girls who regularly attend morning Mass together went to the local Turqueel River in order to gather water with their buckets and to nourish their trees. Additionally, each woman received five USD per tree annually for its care, a welcome and substantial supplement to the-often meager-income of the Turkana women.

\section{Education}

Since the time when Ignatius and his followers formed the Society of Jesus, youth education represents an important part of the Jesuit mission. In Dodoma, as the province's director of development, I am responsible for expanding a secondary school program. Part of this project is funded by the United States Aid in Development's Aid to Schools and Hospitals Abroad program. In my October 2015, quarterly report to a donor I wrote:

The primary objective of the school is to provide high quality education opportunities in the Dodoma region-a region that lags behind in Tanzania in education and human resources. In line with this objective, the school intends and has been able:

(1) to create a community of enquiry, that is, to form students who are not only educated, but critical thinkers with a strong sense of social responsibility.

(2) to cultivate a devotion to the common good among our students and a creative altruism in these future leaders.

(3) to promote education of the girl child. Many gifted girls are left without education in our current culture. The school strives to bring equal opportunities to both genders.

(4) to promote a love for science in order to prepare an innovative and creative generation of men and women who will lead the technological development of Africa and the world.

These objectives are repeated in various ways in our seven other Jesuit-operated education centers in Eastern Africa, which offer a platform from which students and staff may receive an ecological education and also learn that currently the planet is in peril. Through this education, students may come to share Ignatian values and perspectives so that they might make a difference and be a person of change in the world, and this includes a strong environmental component. 
Indeed, ecological education can take many forms, and from my own experience as an educator like other kinds of knowledge it seems that it is basically a matter of transferring knowledge. ${ }^{14}$ While working in Nairobi, as a sort of a chaplain or spiritual guide to both local and international men and women religious, I was sometimes asked to share with them my personal concern for climate change. This became an occasion to collaborate or even to support their own growing concerns for the environment. After all, I was known for having constructed environmentally friendly and beautiful buildings. Via these consultations, some of my best practices were transferred to others. In other capacities, as a member of Rotary International, I was able to take an active role in their agenda for global development, and could amplify some beneficial environmental practices. The Karen Rotary Club, for example, subsequently furnished water wells and helped cultivate the environment around the institutions that it supports, such as Nkaimurunya Primary School.

While the Society has exhibited part of its charism as educators, research and social activism can also represent education in a different mode. In Nairobi, Jesuit Hakimani Center (JHC), an institute that specializes in research, formation, and social action, published in September 2014 its first booklet, an eighty-two-page pamphlet on land use and food security in Kenya, provocatively entitled Climate Change and Food Security: Predictions from the Future..$^{15}$ Addressing future food production in Kenya, they highlighted four critical threats: erratic weather patterns, pollution, poor waste management, and deforestation. There is a need for similar projects that focus on the other countries in the Eastern African province. Elsewhere, in Rumbek, the former capital of South Sudan, at a sister institution called the St Peter Claver Computer and Ecological Training Centre, solar energy development is being instructed alongside computer skills and ecology. ${ }^{16}$ At the nearby campus of the Multi-Educational and Agricultural Jesuit Institute of South Sudan (MAJIS), sustainable agriculture and ecology are an integral parts of the standard curriculum. ${ }^{17}$

14 Ed. note: "ecological education" is a key term in Francis's Laudato si', comprising the sixth chapter, "Ecological Education and Spirituality," n. 202-46.

15 Jesuit Hakimani Centre, http://www.jesuithakimani.net (accessed June 10, 2016). See Climate Change and Food Security: Predictions from the Future (Nairobi: Jesuit Hakimani Centre, 2014).

16 See Jesuits of Eastern African Province, "St Peter Claver Computer and Ecological Training Centre," June 2014, http://jesuits-aor.net/wp-content/uploads/2012/03/St.-Peter-Claver -Computer-Ecological-Training-Centre.pdf (accessed June 10, 2016).

17 See Jesuits of Eastern African Province, "Multi-educational and Agricultural Jesuit Institute of South Sudan," last modified in 2015, http://jesuits-aor.net/wp-content/up loads/2012/o3/MAJIS.pdf (accessed June 10, 2016). 


\section{Conclusion}

While this article does not attempt to be exhaustive regarding the types of ecological initiatives in the Eastern African province, it does outline several kinds of environmental projects illustrating how such issues of justice might be integrated within an educational setting. It highlights the value of collaboration not only between Jesuit provinces, and within provinces, but also with secular organizations, companies, and schools. In a region that is harshly afflicted with the perils of climate change, Jesuits may carry out their missions in the form of accompaniment that combines their specialized - and at times scientific training — with their Ignatian charism. 